\title{
Petrochemical characteristics of Tak volcanic rocks, Thailand: Implication for tectonic significance
}

\author{
Burapha Phajuy*, Vimoltip Singtuen \\ Department of Geological Sciences, Faculty of Science, Chiang Mai University, Chiang Mai 50200 Thailand \\ *Corresponding author, e-mail: buraphaphj3@gmail.com \\ Received 3 Jul 2018 \\ Accepted 6 Aug 2019
}

\begin{abstract}
Tak volcanic rocks, found in the southern part of the Chiang Khong-Lampang-Tak volcanic belt in northern Thailand, provide important evidence of the tectonic evolution of the Palaeotethys ocean. Petrographically and geochemically, the volcanic rocks selected for this study are made up of rhyolite, rhyodacite, andesite porphyry, and basalt. Based on field investigations, these rocks are also associated with other igneous rocks including granite, granodiorite, tuff, gabbro, and cumulus gabbro. The chemical data acquired from X-ray fluorescence, inductively coupled plasma atomic emission spectroscopy, and inductively coupled plasma mass spectrometry methods suggest that the studied rocks from the eruption can be separated into eight magmatic groups and four tectonic settings. The tectonic setting of the southern location of Chiang Khong-Lampang-Tak volcanic rocks consists of (1) an active continental margin (Groups V and VII), (2) a back-arc basin (Group VI), (3) post-collision (Groups II and III), and (4) continental rifting (Groups I, IV, and VIII).
\end{abstract}

KEYWORDS: volcanic rocks, tectonic setting, petrochemistry, Tak volcanic rocks

\section{INTRODUCTION}

The geology of northern Thailand is very irregular, diverse, and obscure. Even though tectonic models which may explain the geological history of this region have been proposed for decades, this idea is still controversial. It is widely accepted that Thailand was an amalgamation of at least two ancient terranes, Shan-Thai and Indochina ${ }^{1}$. The ShanThai Terrane, also known as the Sibumasu Terrane, extends from Sino (China) to Sumatra via west Thailand, Burma, and Malaysia. The Indochina and the Sibumasu Terranes were believed to have originated on the Gondwana Supercontinent in the Devonian and the late Early Permian, respectively ${ }^{2,3}$. The Palaeo-Tethys separated these two cratons during the Palaeozoic, followed by the Late Triassic-Early Jurassic convergence ${ }^{1,4}$.

Many researchers have proposed the existence of a new terrane (Sukhothai terrane or Sukhothai Arc) between the Sibumasu and Indochina ${ }^{4-6}$. They suggested that the tectonostratigraphy of Sukhothai Terrane differs from those of the Sibumasu and Indochina Terranes.

The pre-Cretaceous felsic to mafic volcanic/hypabyssal rocks in the upper part of Thailand may be separated into four belts ${ }^{7}$ from west to east as follows: (1) the Chiang Rai-Chiang Mai volcanic belt,

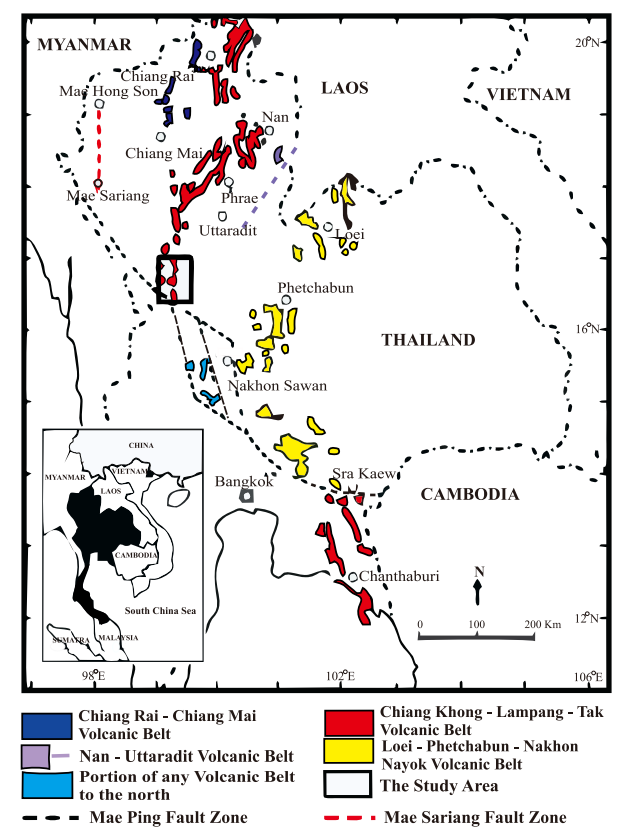

Fig. 1 Distribution of pre-Cretaceous volcanic rocks in the northern part of Thailand ${ }^{7}$.

(2) the Chiang Khong-Lampang-Tak volcanic belt, (3) the Nan-Uttaradit volcanic belt, and (4) the LoeiPhetchabun-Nakhon Nayok volcanic belt (Fig. 1). The Sra Kaew-Chanthaburi volcanic belt may be 
considered part of the Nan-Uttaradit volcanic belt in the north, separated by the Mae Ping fault ${ }^{6}$.

A number of volcanic rocks in Tak province, northern Thailand and the periphery are located in the southern part of the Chiang Khong-LampangTak volcanic belt. These volcanic rocks are traditionally mapped as part of many ages including the Permo-Triassic, Late Triassic, and Early Jurassic ${ }^{8}$. However, the geochemistry of these rocks has not been completely reported. This study focuses on the volcanic rocks in this area with geochemical and petrographic interpretations as well as magmatic grouping. Furthermore, research certainly has an impact on the geology, including the tectonic setting of this volcanic province and the tectonic evolution of Thailand.

\section{Geological setting}

The studied area consists of the provinces of Lampang (Mae Phrik and Thoen districts), Sukhothai (Thung Saliam and Ban Dan Lan Hoi districts), Tak (Ban Tak, Meuang Tak, and Wang Chao districts), and Kamphaeng Phet (Phran Kratai district). The reported geology of this area is based on recent field observations and previous work. According to previous fieldwork ${ }^{8}$, there are 11 rock units of metamorphic and sedimentary rocks as well as sediments. These include: (1) Precambrian metamorphic rocks: orthogneiss, paragneiss, amphibolite schist, quartzmica schist, quartz-kyanite schist, sillimanitemica schist, quartzite, marble, calc-silicate rock, migmatite, and pegmatite; (2) Silurian-Devonian metamorphic rocks; (3) Carboniferous sedimentary and metamorphic rocks; (4) Carboniferous-Permian sedimentary rocks; (5) Lower Permian sedimentary rocks; (6) Middle Permian sedimentary rocks; (7) Triassic sedimentary rocks; (8) Middle Triassic sedimentary rocks; (9) Middle-Upper Triassic sedimentary rocks; (10) Quaternary terrace deposits: gravel, sand, silt, clay, and laterite; and, (11) Quaternary fluvial deposits: gravel, sand, silt, and clay of channels, river banks, and flood basins. The volcanic rocks explored in the current research project have been divided into three igneous rock units as shown on the geological map in Fig. 2. Intrusive igneous rocks distributed in the study area include Triassic granite and mainly consist of biotite granitic rocks with subordinate hornblende granitic rocks and a small amount of pegmatite and aplite. These granitic rocks are grouped in the eastern granite belt of Thailand ${ }^{9}$. A wide range of chemical compositions have been found in the eastern granite belt and classified as an extended series of calcalkaline. These granites formed in an age from 213$256 \mathrm{Ma}^{9}$. Volcanic rocks extend from the north to the south of the study area. They are texturally classified as crystal and lithic ash tuff to agglomerate and volcanic rocks. Petrographically, the rocks are composed of rhyolite, andesite, andesite porphyry, andesitic basalt, rhyolitic tuff, and andesitic tuff. Some subvolcanic rock/shallow intrusive masses intruded the Triassic granite rocks and they are believed to have formed after the upper Triassiclower Jurassic ${ }^{9}$.

\section{MATERIALS AND METHODS}

The method of this study included a field investigation, a petrographic study, and a chemical analysis of least-altered rock samples. The tectonic setting of the eruption of these rocks could be interpreted based on their petrochemistry.

Standard thin sections and powders from the selected samples, as well as loss on ignition (LOI), trace elements, and major oxides analyses, were prepared and studied at the Department of Geological Sciences, Faculty of Science, Chiang Mai University.

A total of 30 representative samples were carefully evaluated under a polarizing microscope to avoid alteration. These least-altered samples were prepared by making powder samples from finely selected rock chips.

Chemical analyses of major oxides $\left(\mathrm{SiO}_{2}, \mathrm{TiO}_{2}\right.$, $\mathrm{Al}_{2} \mathrm{O}_{3}$, Fe total as $\mathrm{Fe}_{2} \mathrm{O}_{3}, \mathrm{MnO}, \mathrm{MgO}, \mathrm{CaO}, \mathrm{Na}_{2} \mathrm{O}$, $\mathrm{K}_{2} \mathrm{O}$, and $\mathrm{P}_{2} \mathrm{O}_{5}$ ) and trace elements $(\mathrm{Rb}, \mathrm{Sr}, \mathrm{Zr}, \mathrm{Y}$, $\mathrm{Nb}, \mathrm{Ni}, \mathrm{Cr}, \mathrm{V}$, and $\mathrm{Sc}$ ) were analysed by a PhillipMagixPro PW 2400 Wavelength Dispersive X-Ray Fluorescence spectrometer. The instrumental parameters consisted of a Rhodium tube with a LiF 200 crystal (used in an elemental range of K-Ru), scintillation and flow proportion detectors, and an X-ray tube operated at $60 \mathrm{kV}$ with a current of up to $125 \mathrm{~mA}$ at a maximum power level of $4 \mathrm{~kW}$. The net (background corrected) intensities were subsequently measured and calculated against calibrations derived from seven international standard reference materials (AGV-2, BCR-2, BHVO-2, BIR-1, DNC-1, GSP-2, and W-2). The SUPER Q 3.0 program was applied using inter-elements matrix corrections. The reporting detection limit was about $0.001 \%$ for major oxides and $3 \mathrm{ppm}$ for trace elements. The accuracy and precision of most of the elements were better than $5 \%$. A major oxides analysis was conducted from fusion disc samples.

LOI was analysed by heating a platinum crucible 


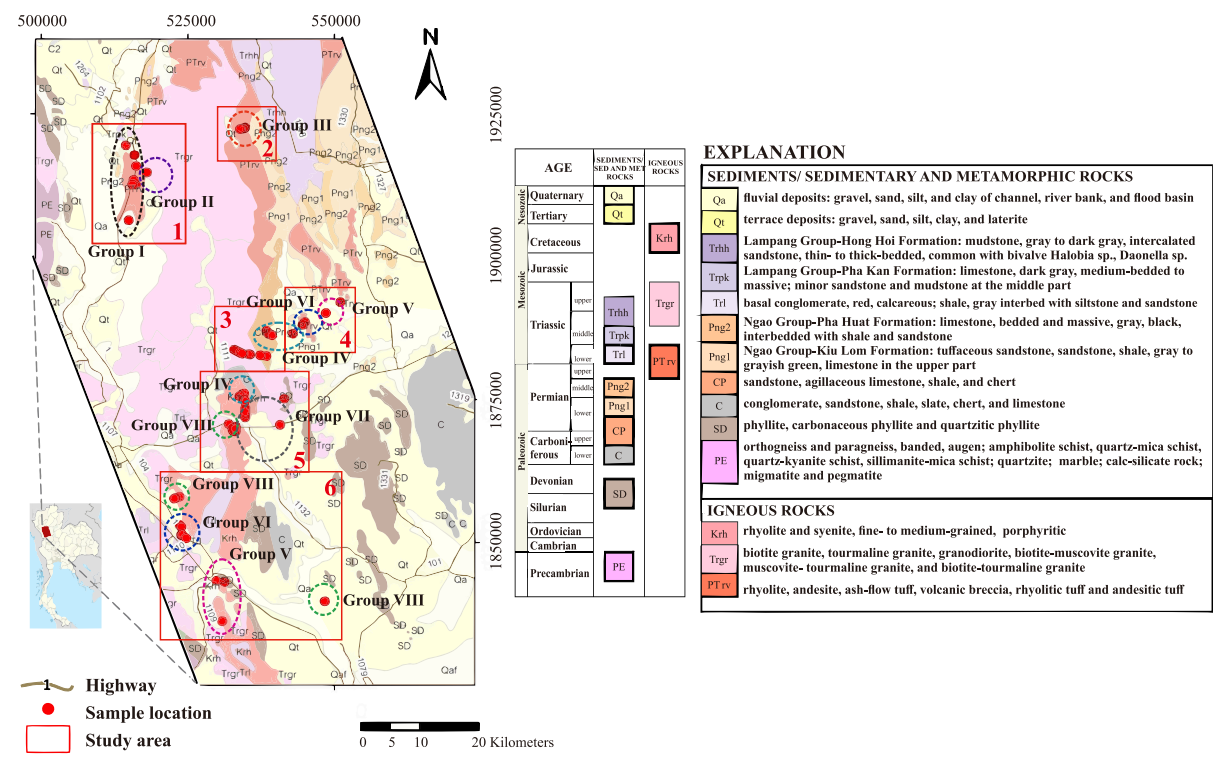

Fig. 2 Geological map of the study area showing the distribution of the rock groups ${ }^{8}$.

containing a $1.0 \mathrm{~g}$ sample in a furnace at $1000^{\circ} \mathrm{C}$ for $12 \mathrm{~h}$ at the Department of Geological Sciences, Chiang Mai University.

The 16 least-altered samples were selected for their low levels of trace elements (Hf, Th, and Ta) and rare earth elements (La, Ce, Pr, Nd, Sm, Eu, $\mathrm{Gd}, \mathrm{Tb}, \mathrm{Dy}, \mathrm{Ho}, \mathrm{Er}, \mathrm{Tm}$, and $\mathrm{Yb}$ ) and were analysed using a Sodium Peroxide Fusion combined inductively coupled plasma atomic emission spectroscopy and inductively coupled plasma mass spectrometry at the SGS-CSTC Standards Technical Services Co., Ltd., China.

\section{RESULTS}

\section{Petrography}

The features, alterations, and mineral compositions suggested that the studied rocks could be defined as rhyolite, rhyodacite, andesite, basalt, gabbro, and cumulus gabbro.

Rhyolitic and rhyodacite outcrops were found in gullies along road-cuts and as in situ float rocks. Their textures were porphyritic to slightly porphyritic and fine to very fine-grained (Fig. S1(ab)). The phenocrysts/microphenocrysts were largely made up of quartz and plagioclase, with small amounts of alkali feldspar and opaque minerals ${ }^{10}$. The groundmass phase of rhyolite was comprised of quartz-alkali feldspar intergrowths (granophyric and spherulitic) with small amounts of quartz, alkali feldspar, muscovite, and opaque minerals. This rhyolite was associated with rhyolitic welded tuff.
In addition, the groundmass phase of rhyodacite was mainly composed of quartz-alkali feldspar devitrification with small amounts of quartz, alkali feldspar and chlorite. Andesitic outcrops were observed in road-cut outcrops and in situ rocks. The andesite showed porphyritic and very finegrained textures (Fig. S1(c)). Furthermore, the phenocrysts/microphenocrysts were comprised of plagioclase with small amounts of unidentified mafic minerals, clinopyroxene, and opaque minerals. The phenocrysts/microphenocrysts formed glomerocrysts and cumulocrysts ${ }^{11}$. The groundmass phase was mainly composed of plagioclase, with small amounts of unidentified mafic minerals, opaque minerals, and apatite.

Basaltic outcrops were found in a feldspar mine, at the chill margin of the dike, and presented as in situ rocks outside. They showed a slightly porphyritic texture, and the phenocrysts/microphenocrysts were largely comprised of plagioclase with a small amount of unidentified mafic minerals (Fig. S1(d)). The groundmass phase mainly consisted of plagioclase, with small amounts of unidentified mafic and opaque minerals. Plagioclase and clinopyroxene in the groundmass phase were ophitic/subophitic intergrowth.

Gabbroic rocks were found in small hills as in situ float rocks and showed a fine to mediumgrained texture (Fig. 3). They were largely composed of plagioclase and clinopyroxene, with subordinate unidentified mafic and opaque minerals (magnetite). Plagioclase and clinopyroxene in the 


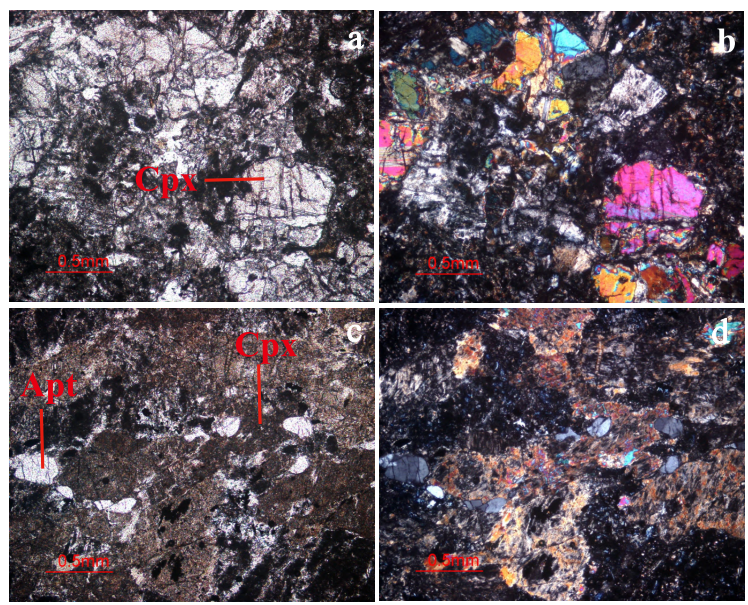

Fig. 3 The photomicrographs of gabbro (sample number WL29/2-2) showing ophitic/subophitic intergrowth; clinopyroxene (Cpx) (a) ordinary light (b) crossed polars and the photomicrographs of cumulus gabbro (sample number WL29/1-2) showing apatite (Apt) inclusion in clinopyroxene (Cpx) crystals (c) ordinary light (d) crossed polars.

groundmass phase were ophitic/subophitic intergrowth.

The cumulus gabbro was equigranular and showed a cumulus texture (Fig. 3). The cumulus crystals were mainly made up of plagioclase with subordinate clinopyroxene and unidentified mafic minerals and a small amount of apatite. The intercumulus crystals comprised hornblende and opaque minerals (magnetite). Patches of calcite, chlorite, epidotes, and clay minerals occasionally replaced some minerals in these rocks.

\section{Geochemistry and magmatic affinity}

Table S1 shows the analytical results for major oxides, trace elements, REE, Ta, and Hf analysis of the studied volcanic and associated samples. As the representative volcanic and associated rocks contained different quantities of trace elements (shown in REE patterns, multielement pattern, and variation diagrams), they could be separated into eight magmatic groups (Fig. 2). Petrographic analyses showed that the studied rock samples experienced alteration. The alteration types were studied using an alteration index diagram ${ }^{12,13}$ (Fig. 4a). Group I and II rocks were strongly altered $([\mathrm{K}+\mathrm{Na}+2 \mathrm{Ca}] / \mathrm{Al}<1)$, and the others were slightly altered; however, major oxides in these samples were mobile. Accordingly, immobile elements were selected for the chemical interpretation in this study.
The studied rock samples were located within the fields of rhyolite, rhyodacite/dacite, andesite, andesite/basalt, subalkaline basalt, and alkali basalt in the $\mathrm{Zr} / \mathrm{TiO}_{2}$ versus $\mathrm{Nb} / \mathrm{Y}$ diagram ${ }^{14}$ (Fig. 4b).

The Group I rocks (BTK25/1-1, BTK25/1-2, and BTK 25/7), Group II rocks (BTK 25/8-1 and BTK 25/8-3), and Group III rocks (MSL25/1-1) were all distributed in the northern part of the study area. The Group I rocks were made up of rhyodacite. Group II rocks, composed of basalt, were in the Mae Phrik area and cut along a Triassic granitic intrusion. The Group III rocks consisted of rhyolite. The Group IV rocks (PDNG30/4, WL29/1-1, WL29/1-2, WL29/1-3, WL29/2-1, and WPC26/4) were generally located in the central part of the study area. They included basalt porphyry, cumulus gabbro, and andesite porphyry. The Group V rocks (WL29/2-2, WCH28/4, and WCH28/8-1) were distributed in the central and southern parts of the study area, and included gabbro, andesite, and basalt. Group VI rocks (WL29/3 and WCH26/4), distributed in the central and southern parts of the study area, were comprised of gabbro and rhyolite. The Group VII rocks (WPC26/7, WPC26/10, WPC26/11, WPC26/12, WPC27/2, and WPC27/3) were distributed in the central parts of the study area and were made up of andesite porphyry. Lastly, the Group VIII rocks (WPC26/3-1, WCH26/2-1, WCH26/2-2, WCH26/3-1, WCH26/3-2, WCH26/5, and WCH27/5-2) were distributed in the central and southern parts of the study area and composed of rhyolite.

\section{Tectonic discrimination}

Almost of the rhyolite and rhyodacite studied (Groups I, III, and VIII), except for WPC26/3-1, are presented in a within-plate granite field ${ }^{10}$ in both Y-Nb (Fig. 5a) ${ }^{15}$ and (Y+Nb)-Rb (Fig. 5b) ${ }^{15}$. WPC26/3-1 emerged in the Y-Nb diagram to be an orogeny granite field ${ }^{10}$. Field data potentially supported and advocated the occurrence of chill margins of granite intrusives.

The Group II rocks are plotted in the fields of a volcanic arc and a within-plate basalt in the Ti-Zr (Fig. 6a) ${ }^{16}$ diagrams.

The Group IV rocks mostly emerged in the fields of a volcanic arc as shown in the following diagrams. Ti-Zr (Fig. 6) ${ }^{16,17}$ and Zr-Nb-Y (Fig. 7a) ${ }^{18}$. Their occurrence in within-plate basalt in Zr-Nb-Y and ZrTi-Y is noted in Fig. $7 \mathrm{a}^{18}$ and Fig. $7 \mathrm{~b}^{17}$ diagrams, respectively. However, the mid-oceanic ridge basalt is presented in Ti-Zr (Fig. 6) ${ }^{16,17}$ and V-Ti (Fig. 7a) ${ }^{18}$ diagrams and the calc-alkalic basalt is shown in $\mathrm{Zr}$ - 

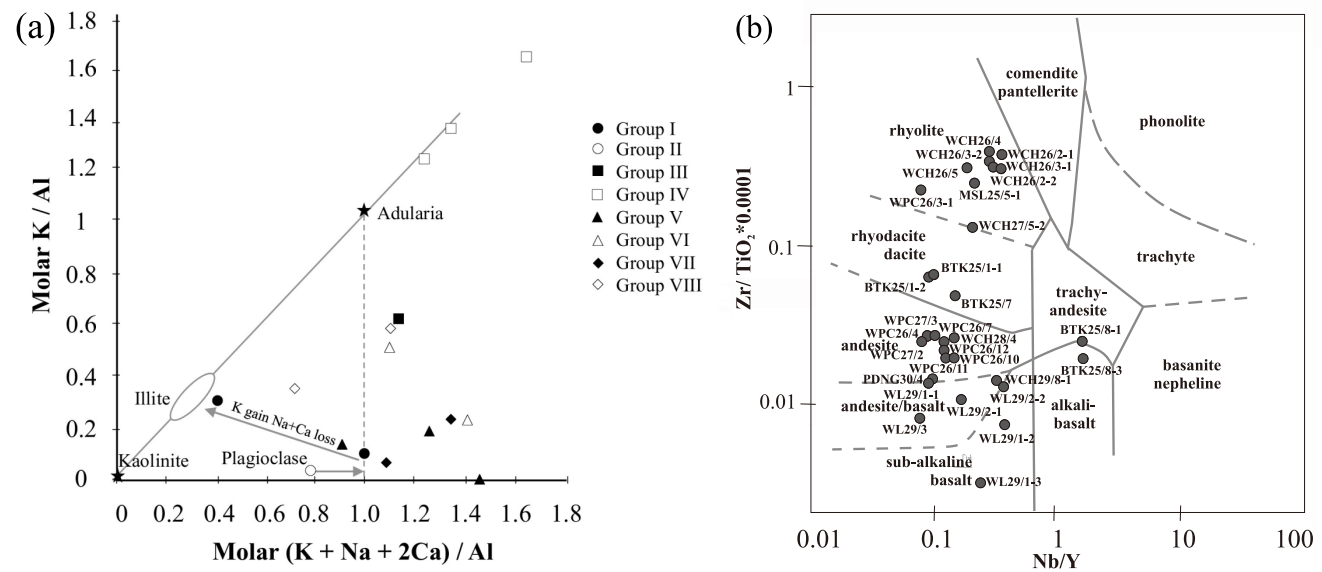

Fig. 4 (a) Molar $\mathrm{K} / \mathrm{Al}$ versus molar $(\mathrm{K}+\mathrm{Na}+2 \mathrm{Ca}) / \mathrm{Al}^{12,13}$. The alteration minerals kaolinite, illite and adularia were plotted on a line of slope 1 . Unaltered igneous rocks typically have molar $(\mathrm{K}+\mathrm{Na}+2 \mathrm{Ca}) / \mathrm{Al}$ values $>1$. Potassium metasomatism leads to decreasing molar $(\mathrm{K}+\mathrm{Na}+2 \mathrm{Ca}) / \mathrm{Al}$ and increasing molar $\mathrm{K} / \mathrm{Al}$ values. (b) $\mathrm{Plot}$ of $\mathrm{Zr} / \mathrm{TiO}{ }_{2} \mathrm{against}$ $\mathrm{Nb} / \mathrm{Y}^{14}$ for the studied volcanic and associated rocks.
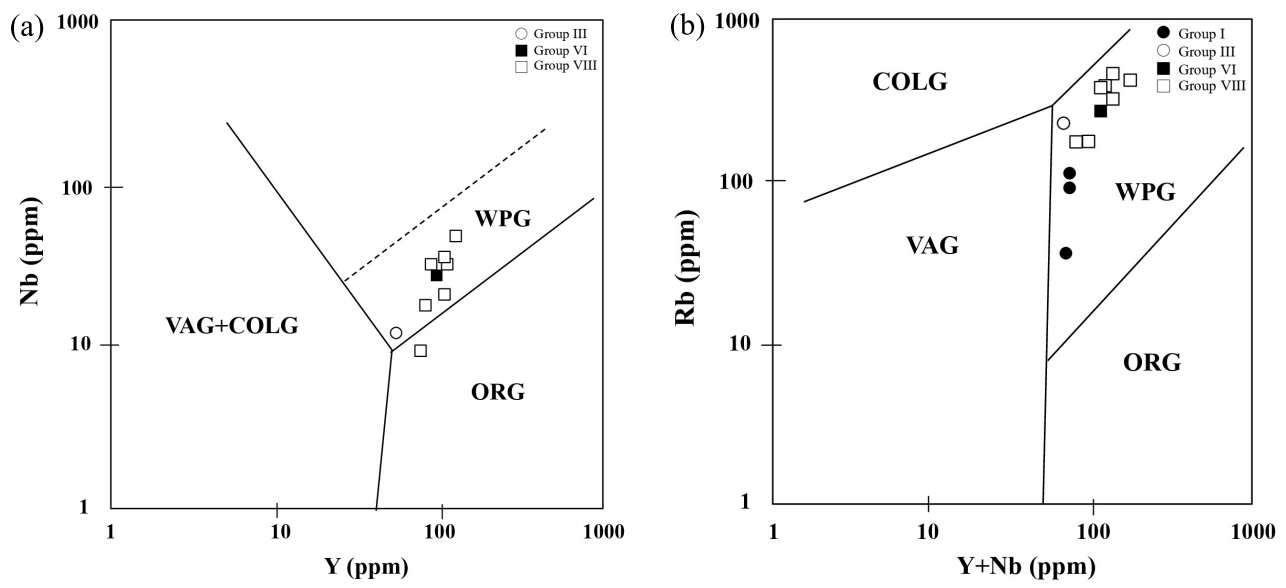

Fig. 5 (a) Y versus $\mathrm{Nb}$ plots ${ }^{15}$ for the studied felsic volcanic rocks, (b) (Y+Nb) versus $\mathrm{Rb}^{15}$ plots for the studied felsic volcanic rocks. The fields are as follows. VAG $=$ volcanic arc granite, COLG $=$ collision orogeny granite, WPG $=$ within-plate granite, and ORG $=$ orogeny granite.
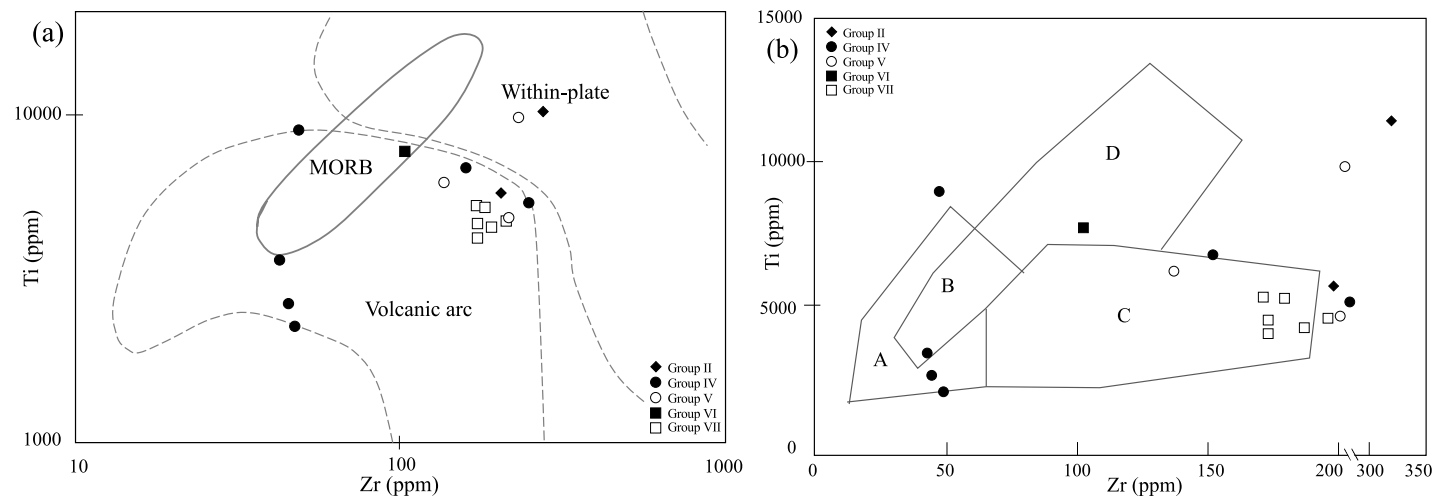

Fig. 6 Ti-Zr discrimination diagram ${ }^{16,17}$ for the studied mafic volcanic and associated rocks. The fields are as follows. MORB = mid-oceanic ridge basalt, $\mathrm{A}=$ island-arc tholeiites, $\mathrm{B}=\mathrm{MORB}+\mathrm{C}-\mathrm{A}$ bas+IAT, calc-alkali basalts, and island-arc tholeiites, $\mathrm{C}=$ calc-alkali basalts, and $\mathrm{D}=$ mid-oceanic ridge basalt. 


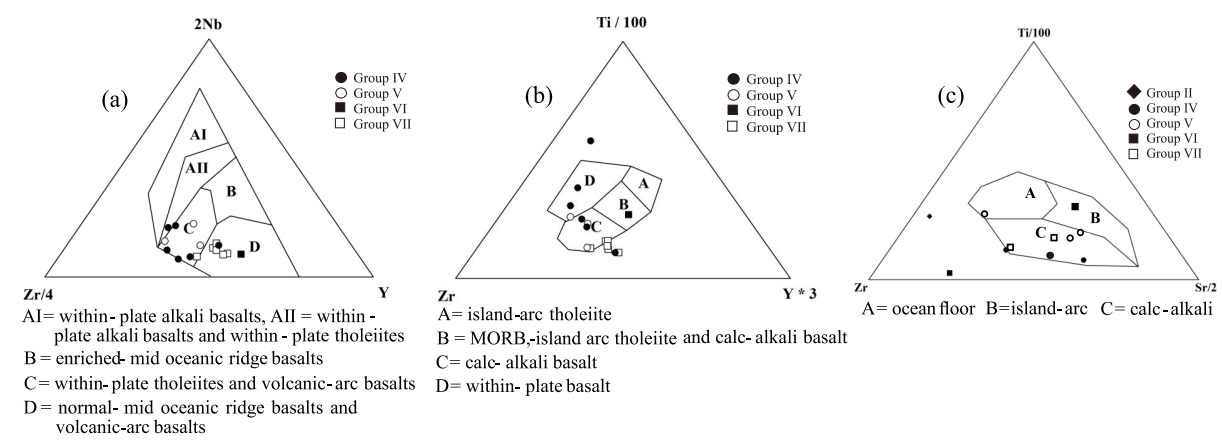

Fig. 7 The discrimination diagrams for the studied mafic volcanic and associated rocks: (a) Zr-Nb-Y diagram ${ }^{18}$, (b) ZrTi-Y diagram ${ }^{17}$, and (c) Ti-Zr-Sr diagram ${ }^{19}$.

Ti-Y (Fig. 7b) ${ }^{17}$ and Ti-Sr-Zr (Fig. 7c) ${ }^{19}$ diagrams.

The Group V rocks are primarily presented in fields of within-plate basalt as demonstrated in Ti-Zr (Fig. 6a) ${ }^{16}$, Zr-Nb-Y (Fig. 7a) ${ }^{18}$, and ZrTi-Y (Fig. 7b) ${ }^{17}$ diagrams. However, these rocks are shown in a calc-alkalic basalt field, as evidenced in the diagram plots of Ti-Zr (Fig. 6b) ${ }^{17}$, Zr-Ti-Y (Fig. 7b) ${ }^{17}$ and Ti-Sr-Zr (Fig. 7c) ${ }^{19}$, and the volcanic arcs in Ti-Zr (Fig. $6 \mathrm{a})^{16}$ and Zr-Nb-Y (Fig. 7a) ${ }^{18}$. There could well be ocean floor in the plot of Ti-Sr-Zr (Fig. 7c) ${ }^{19}$ diagram.

Group VI rocks are largely distributed around the boundary of mid-oceanic ridge basalt as shown in the following diagrams. Ti-Zr (Fig. 6a) ${ }^{16}$, ZrNb-Y (Fig. 7a) ${ }^{18}$, and Zr-Ti-Y (Fig. 7b) ${ }^{17}$. Volcanic arcs emerge in the Zr-Nb-Y (Fig. 7a) ${ }^{18}$, Zr-Ti-Y (Fig. 7b) ${ }^{17}$, and Ti-Sr-Zr (Fig. 7c) ${ }^{19}$ diagrams and calc-alkalic basalt is shown in the Zr-Ti-Y (Fig. 7b) ${ }^{17}$ diagram.

Group VII rocks, generally located in the fields of volcanic arc11, appear in the Ti-Zr (Fig. 6a) ${ }^{16}$ and Zr-Nb-Y (Fig. 7a) ${ }^{18}$ diagrams. While these rocks are shown in a calc-alkalic basalt field, as evidenced in the plotting of Ti-Zr (Fig. 6b) ${ }^{17}, \mathrm{Zr}-$ Ti-Y (Fig. 7b) ${ }^{17}$, and Ti-Sr-Zr (Fig. 7c) ${ }^{19}$ diagrams, mid-oceanic ridge basalt, and within-plate basalt are presented in the Zr-Nb-Y (Fig. 7a) ${ }^{18}$ diagram.

\section{Modern analogue}

Similarities appeared when comparing rare earth elements (REE) and immobile trace elements in the studied samples with modern magmatic rocks that clarified when forming in a tectonic setting. The chemical comparisons specifically focused on REE-patterns ${ }^{20}$ and on N-MORB normalized multielement patterns ${ }^{21}$. The chemical composition of igneous rocks, especially rare earth elements and immobile incompatible elements, within each tec- tonic setting were found to be different and specific.

The Group I rocks were typical examples of mildly calc-alkaline series REE patterns. The chemical compositions of some Group I rocks were very similar to Miocene intra-plate rhyolites from Jabal Shama, Saudi Arabia ${ }^{22}$, which had been formed within a plate on the rifting stage in the western portion of the Arabian shield (Fig. 8). This finding is consistent with results of previous tectonic discrimination diagrams associated with within-plate settings.

Chemically, the Group II rocks were typical of alkaline series REE patterns. The chemical composition of representative Group II rocks were comparable to the Miocene basaltic dike from Miocene magmatism in Tibet ${ }^{23}$, which had been formed postcollision between India and the Eurasia plates in the northern Himalayan orogeny and cross cut into granitic rocks (Fig. 8). This analysis does not correspond to results from previous tectonic discrimination diagrams, which were done outside of the field of post-collision setting. However, a post-collision setting is most appropriate for both volcanic arcs and within-plate settings.

Group III rhyolites were typical examples of calc-alkaline series REE patterns. The chemical composition of these representative Group III rocks was very similar to that of the Miocene rhyolite porphyry from Miocene magmatism at Yaguila, Tibet ${ }^{23}$, which had been formed post-collision between India and the Eurasia plates in the northern Himalayan orogeny (Fig. 8). Although there was not a postcollision field in the previous discrimination diagrams, this analysis is consistent with a within-plate tectonic setting.

Furthermore, the Group IV rocks showed typical mildly alkaline series of REE patterns. The REE patterns for the cumulus gabbro had positive $\mathrm{Eu}$ 

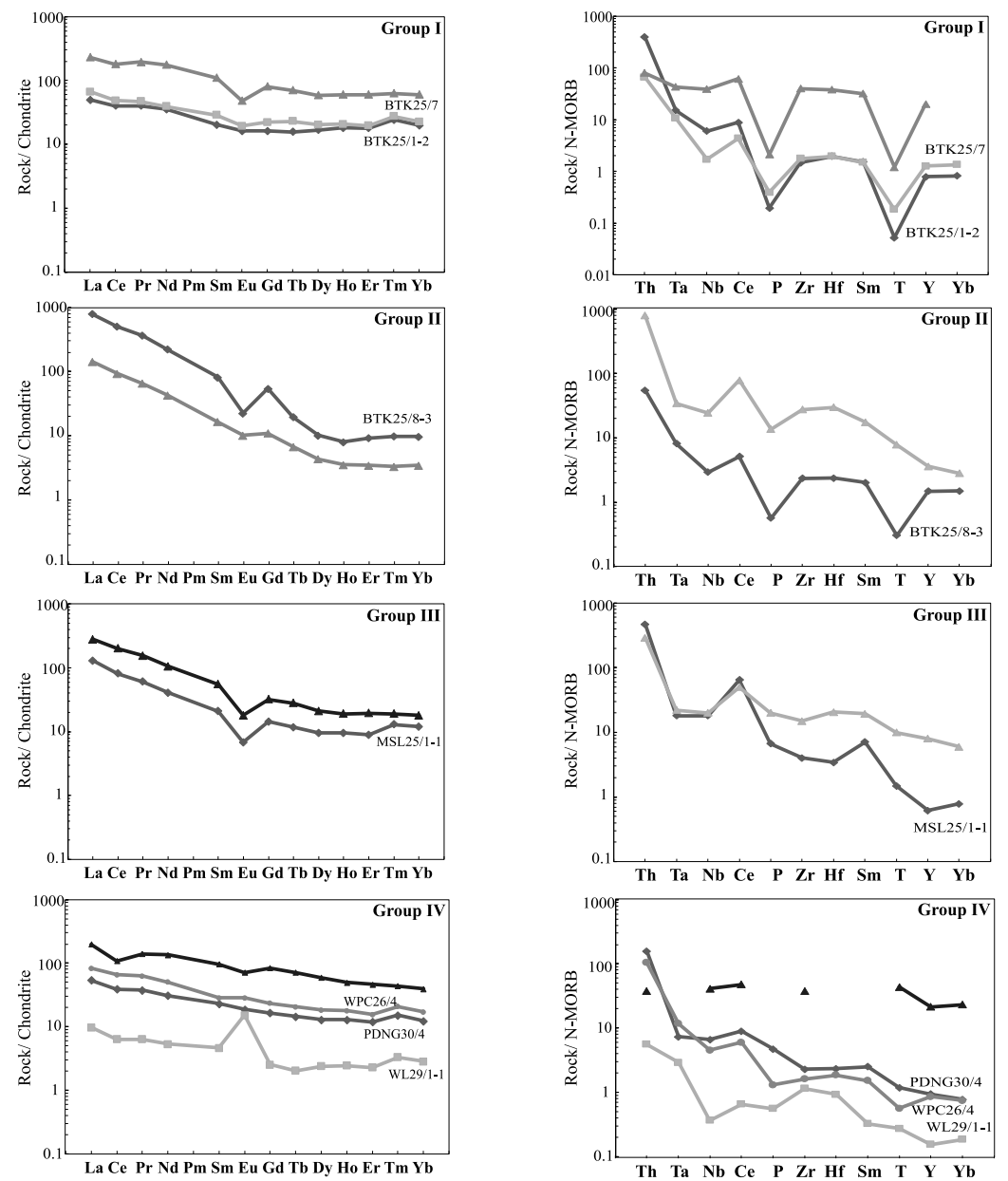

Fig. 8 Chondrite-normalized REE patterns ${ }^{20}$ and N-MORB normalized multielement patterns ${ }^{21}$ for the studied rocks and their modern analogue (solid triangle); Group I ${ }^{22}$, Group $\mathrm{II}^{23}$, Group III ${ }^{23}$, and Group $\mathrm{IV}^{24}$.

anomalies, and were controlled by cumulative plagioclases. The chemical compositions of representative Group IV rocks were most comparable with Cretaceous basalt from the Karoo volcanic rocks, Mozambique ${ }^{24}$, which had been formed withinplate in south-eastern Africa (Fig. 8). This fact is consistent with results of previous tectonic discrimination diagrams in within-plate tectonic settings.

Furthermore, the Group V rocks typically had alkaline series REE patterns. The chemical compositions of representative Group V rocks were similar to Quaternary basalt from the Central Volcanic Zone in Southern Peru ${ }^{25}$, which had formed an active continental margin in the central Andes (Fig. 9). This analysis agrees with the results of previous tectonic discrimination diagrams, and the findings were based on the calc-alkali magma that occurred in the volcanic arc setting or on the active continental margin.
Chemically, the Group VI rocks were typical examples of tholeiitic series REE patterns. The chemical compositions of the Group VI rocks were most comparable to the Late Miocene Topaz-bearing rhyolite from the Chivinar volcano, NW Argentina ${ }^{26}$, which had been formed in an immature back-arc setting in the eastern Andes (Fig. 9). This fact does not agree with the results of previous tectonic discrimination diagrams, which had been not been in a back-arc basin setting. However, back-arc settings are most appropriate for Mid-Oceanic Ridge settings based on their chemical compositions and rate of occurrence.

The Group VII rocks typically showed mildly calc-alkaline series REE patterns ${ }^{11}$. The chemical compositions of Group VII rocks were very similar to Quaternary aphyric high-K andesite from the Ollagüe volcano region, Chile ${ }^{27}$ which had been formed as an active continental margin in the cen- 

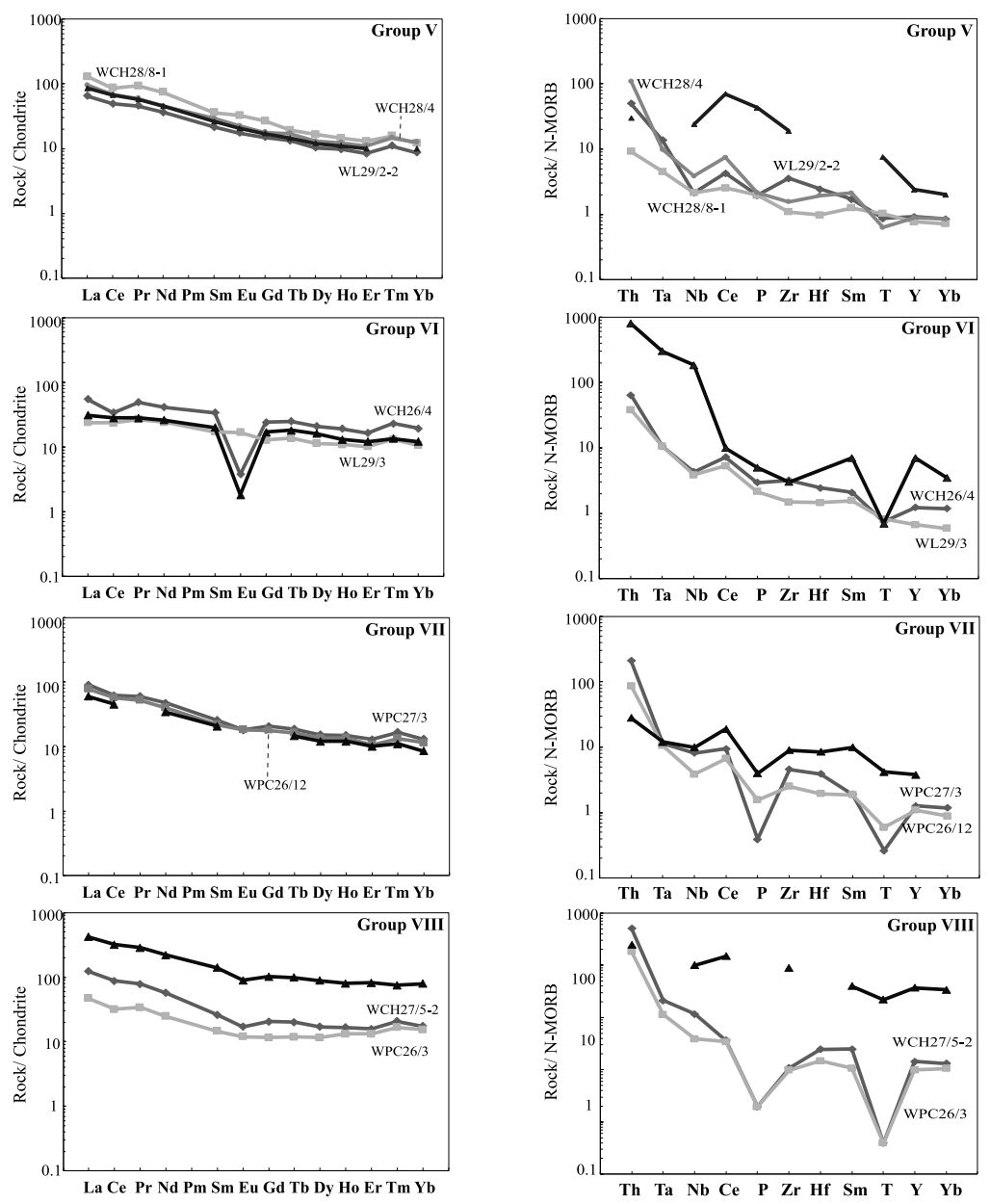

Fig. 9 Chondrite-normalized REE patterns ${ }^{20}$ and N-MORB normalized multielement patterns ${ }^{21}$ for the studied rocks and their modern analogue (solid triangle); Group V ${ }^{25}$, Group VI ${ }^{26}$, Group VII ${ }^{27}$, and Group VIII ${ }^{24}$.

tral Andes (Fig. 9). This analysis is consistent with results from previous tectonic discrimination diagrams, and the findings are due to the presence of the calc-alkali magma that occurred in volcanic arc settings or on an active continental margin.

Chemically, the Group VIII rocks were typical of mildly calc-alkaline series REE patterns. The chemical compositions of Group VIII rocks were similar to the Miocene within-plate rhyolite from the Karoo volcanic rocks, Mozambique ${ }^{24}$ which had been formed as a within-plate in south-eastern Africa (Fig. 9). This fact is in accordance with results of previous tectonic discrimination diagrams for the within-plate settings.

\section{DISCUSSION OF TECTONIC IMPLICATIONS}

Petrochemically, the volcanic and associated rocks studied could be separated into eight magmatic groups, from Group I to Group VIII. They derived from different magmatic affinities, from subalkalic to alkaline magma series, and had been formed in different tectonic settings ${ }^{28}$.

The landmass forming Thailand is generally believed to be the result of the collision between Shan-Thai and Indochina ${ }^{1}$. The major ocean basin that separated Shan-Thai from Indochina may be represented by the Chiang Rai-Chiang Mai volcanic belt, the Nan-Uttaradit volcanic belt or the LoeiPhetchabun-Nakhon Nayok volcanic belt. Many researchers have proposed the existence of a new terrane (Sukhothai terrane or Sukhothai Arc) between the Sibumasu and Indochina ${ }^{4,5}$. The Chiang Khong-Lampang-Tak volcanic belt is part of the igneous rocks of this Sukhothai Terrane. A number of researchers believe that the volcanic rocks in this belt erupted in a subduction-related environment or continental arc environment ${ }^{1,29}$. Later on, this volcanic belt was reported that formed in 
a post-orogenic setting ${ }^{30,31}$. U-Pb zircon dating was carried out on the Permo-Triassic arc-related volcanic rocks along the western edge of Mae Moh $\operatorname{Basin}^{32}$ and the northern end of this belt ${ }^{33}$. The results revealed that the volcanic rocks had $\mathrm{U}-\mathrm{Pb}$ Zircon ages of $240 \pm 1 \mathrm{Ma}$ (Middle Triassic) and 232.9 \pm 0.4 Ma (Middle Triassic), respectively. On the other hand, Khositanont et al determined that the volcanic rocks in the Lampang and Phrae areas had U-Pb Zircon ages of $247 \pm 5-219 \pm 3 \mathrm{Ma}$ and mentioned that they erupted in the early to late Triassic period ${ }^{34}$. This finding was consistent with Srichan ${ }^{35}$, who reported that Chiang KhongLampang-Tak volcanic rocks occurred in the MiddleLate Triassic (233 $\pm 5-220 \pm 5 \mathrm{Ma}$ ) as a result of the post-collisional activity. Qiang et al reported that volcanic rocks from the Chiang Khong area yielded a zircon U-Pb age of $229 \pm 4 \mathrm{Ma}^{36}$, significantly younger than the continental-arc and syn-collisional volcanic rocks $(238-241 \mathrm{Ma})^{37}$.

The northern and central parts of the Chiang Khong-Lampang-Tak volcanic belt have only reported and interpreted a tectonic model, except for the southern end that is complex due to a volcanic eruption period. For this study, the tectonic setting of the studied volcanic and associated rocks in the southern part of Chiang Khong-LampangTak volcanic belt could be separated into an active continental margin (Groups V and VII), a back arc (Group VI), post-collision (Groups II and III) and continental rifting (Groups I, IV, and VIII).

However, missing age dating of the studied rocks has not reconstructed a tectonic model. The analogue comparisons suggested that the studied rocks have the same age as the Chiang Khong-Lampang-Tak volcanic belt. The Group III rocks were chemically comparable with microdiorite in the Chiang Khong area ${ }^{30}$. Their chondritenormalized REE patterns showed a relatively flat REE pattern from Sm to $\mathrm{Yb}$, and were slightly LREE enriched (Fig. 10). This REE patterns were typical of a calc-alkaline series and showed a post-collision pattern like their modern analogue. The Group III rocks may have the same age as microdiorite and may have been erupted in the Middle-Late Triassic $(223 \pm 8 \mathrm{Ma})^{30}$. The Group VII rocks are quite similar to andesite in chemical composition in the Doi Yao volcanic zone, Chiang Khong area ${ }^{37}$. The chondrite-normalized REE patterns of Group VII rocks and their analogue showed a relatively flat REE pattern from $\mathrm{Sm}$ to $\mathrm{Yb}$, and were slightly LREE enriched (Fig. 10). These REE patterns were typical of a calc-alkaline series and showed a geochemical affinity to an arc pattern like their modern analogue. The microdiorite was analysed by Qian et al and were aged in $241.2 \pm 4.6$ Ma (early Middle Triassic) ${ }^{37}$; they may be consistent with Group VII rocks.

Tectonically, Group V and Group VII rocks might have occurred in an active continental margin in 241.2 \pm 4.6 Ma (early Middle Triassic) (Fig. 11a). Contemporaneously, Group VI rocks may have erupted in a back-arc basin that might have started rifting for a short time after the Middle Triassic and before the Late Triassic period ${ }^{28}$. Group II and III rocks might have erupted in a post-collision setting in $223 \pm 8$ Ma (Late Triassic) (Fig. 11b). Group I, IV, and VIII rocks might have erupted in continental rifting in the Late Triassic to Early Jurassic (Fig. 11c). This episode has been considered as the main tectonic event of the Indosinian orogeny stage that resulted from the Shan Thai (or Sibumasu) and Indochina collision in the Malaysian Peninsular and Sumatra ${ }^{38}$. The Indosinian orogeny is the primary cause of block faulting in the Sukhothai foldbelt ${ }^{39}$, and might have made a thin plate in this area with rifting magmatic activity.

\section{CONCLUSIONS}

The studied volcanic rocks were located in the southern part of the Chiang Khong-Lampang-Tak volcanic belt, which mainly lies in the Sukhothai Terrane of Thailand. Petrochemical data show that the Tak volcanic rocks consist of rhyolite, rhyodacite, andesite porphyry, and basalt. These rocks are also associated with tuff, gabbro, and cumulus gabbro. However, as suggested by their features, alterations, and chemical compositions, some volcanic and associated rocks might have occurred in conjunction with Triassic granitic rocks. These studied rocks can be divided into eight magmatic groups, Group I to Group VIII. These groups were derived from different magmatic affinities, subalkalic to alkaline magma series, and had been formed in different ages and tectonic settings.

1. Group V and Group VII rocks (andesite, basalt, and gabbro) erupted at an active continental margin in the early Middle Triassic period. At the same time, Group VI rocks (rhyolite and gabbro) formed in the back-arc basin.

2. Group II and Group III rocks (rhyolite and basalt) erupted at post-collision setting in the Late Triassic.

3. Group I, Group IV, and Group VIII rocks (rhyodacite, andesite, basalt, and gabbro) erupted at continental rifting in Late Triassic to Early Jurassic. Absolute age dating of the volcanic rocks in this 

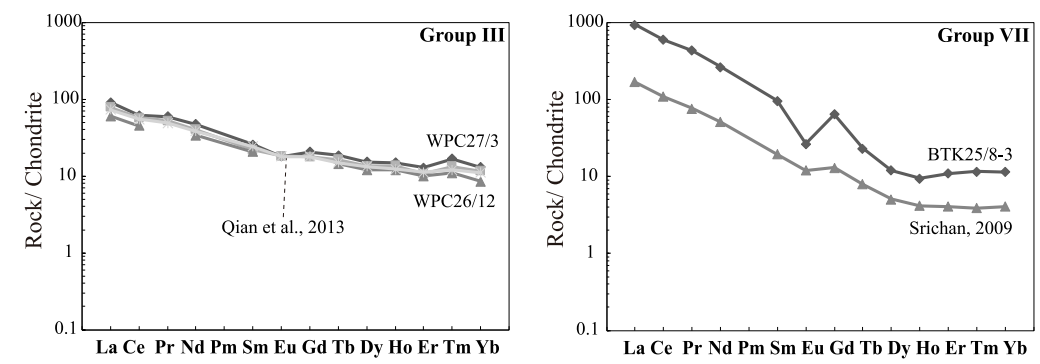

Fig. 10 Chondrite-normalized REE patterns ${ }^{20}$ of Group III rocks and Group VII rocks and their analogue ${ }^{30,37 .}$

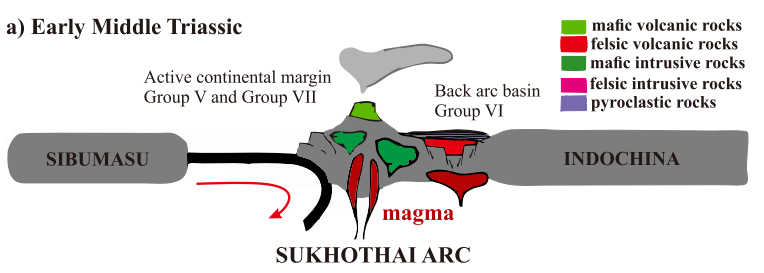

b) Late Triassic

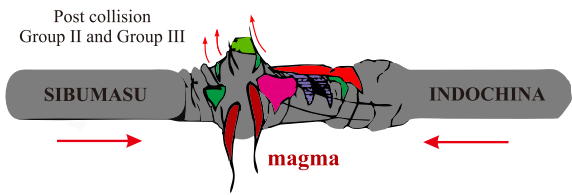

c) Late Triassic-Early Jurassic

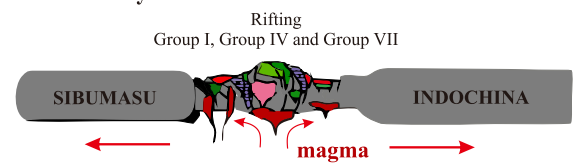

Fig. 11 Schematic diagrams of the tectonic evolution of Shan Thai (or Sibumasu) and Indochina terranes. (a) Active continental margin and back arc stage in Middle Triassic, (b) completely collision stage in early late Triassic and post-collision stage in late Triassic, and (c) rifting stage during late Triassic to early Jurassic.

area will clarify tectonic evolution and reconstruct the tectonic model.

Acknowledgements: The authors would like to express our sincere gratitude to the Igneous Rocks and Related Ore Deposits Research Laboratory (IROL) of the Department of Geological Sciences, Faculty of Science, Chiang Mai University. In addition, we thank the Science Achievement Scholarship of Thailand (SAST) for their financial support for the second author. Thanks are also extended to anonymous referees for their valuable comments and advice.

\section{Appendix A. Supplementary data}

Supplementary data associated with this article can be found at http://dx.doi.org/10.2306/ scienceasia1513-1874.2019.45.350.

\section{REFERENCES}

1. Bunopas S (1981) Paleogeographic history of western Thailand and adjacent parts of Southeast Asiaa plate tectonics interpretation. $\mathrm{PhD}$ thesis, Victoria Univ of Wellington, New Zealand.

2. Metcalfe I (2011) Tectonic framework and Phanerozoic evolution of Sundaland. Gondwana Res 19, 3-21.

3. Metcalfe I (2013) Gondwana dispersion and Asian accretion: tectonic and palaeogeographic evolution of eastern Tethys. $J$ Asian Earth Sci 66, 1-33.

4. Sone M, Metcalfe I (2008) Parallel tethyan sutures in mainland SE Asia: new insights for palaeo-Tethys closure. C R Geosci 340, 166-179.

5. Ueno K, Hisada K (2001) The Nan-Uttaradit-Sa Kaeo suture as a main paleo-Tethyan suture in Thailand: is it real?. Gondwana Res 4, 804-806.

6. Sone M, Metcalfe I, Chaodumrong P (2012) The Chanthaburi terrane of southeastern Thailand: stratigraphic confirmation as a disrupted segment of the Sukhothai arc. J Asian Earth Sci 61, 16-32.

7. Kosuwan P (2013) Petrochemistry and tectonic significance of volcanic rocks in Nakhon Sawan and Uthai Thani provinces, Thailand. PhD thesis, Chiang Mai Univ, Thailand.

8. DMR (2007) Geologic Data of Thailand, Department of Minerals and Resources, Bangkok, Thailand.

9. Mahawat J (1982) The petrology and geochemistry of the granitic rocks of the Tak batholith, Thailand. PhD thesis, Liverpool Univ, UK.

10. Singtuen M, Phajuy B (2017) Petrography and geochemistry of Felsic extrusive rocks in southern part of the Chiang Khong-Lampang-Tak volcanic belt, Thailand. In: Proceeding of 6th International Graduate Research Conference, Chiang Mai, pp 27-32.

11. Singtuen M, Phajuy B (2016) Geochemistry and tectonic significance of Andesitic Rocks in Tak province, Thailand. In: Proceeding of 52nd CCOP Annual Session Geoscience for the Society, Bangkok, pp 65-74.

12. Madeisky HE (1996) A lithogeochemical and radiometric study of hydrothermal alteration and metal zoning at the Cinola epithermal gold deposit, Queen Charlotte Islands, British Columbia. In: Proceedings of the Symposium, Geology and ore deposits of the 
American Cordillera, Nevada, pp 1153-1185.

13. Booden MA, Smith IEM, Mauk JL, Black PM (2010) Evolving volcanism at the tip of a propagating arc: the earliest high-mg andesites in northern New Zealand. J Volcanol Geotherm Res 195, 83-96.

14. Winchester JA, Floyd PA (1977) Geochemical discrimination of different magma series and their differentiation products using immobile elements. Chem Geol 20, 325-343.

15. Pearce JA, Harris NBW, Tindle AG (1984) Trace element discrimination diagrams for the tectonic interpretation of granitic rocks. J Petrol 25, 956-983.

16. Pearce JA (1982) Trace Element Characteristics of Lavas from Destructive Plate Boundaries, John Wiley \& Sons, New York.

17. Pearce JA, Cann JR (1973) Tectonic setting of basic volcanic rocks determined using trace element analyses. Earth Planet Sci Lett 19, 290-300.

18. Meschede M (1986) A method of discriminating between different types of mid-ocean ridge basalts and continental tholeiites with the Nb-Zr-Y diagram. Chem Geol 56, 207-218.

19. Pearce TH, Gorman BE, Birkett TC (1977) The relationship between major element chemistry and tectonic environment of basic and intermediate volcanic rocks. Earth Planet Sci Lett 36, 121-132.

20. Sun SS, McDonough WF (1989) Chemical and isotopic systematics of oceanic basalts; implications for mantle composition and processes. J Geol Soc London 42, 313-345.

21. Taylor SR, Gorton MP (1977) Geochemical application of spark source mass spectrography-III. Element sensitivity, precision and accuracy. Geochim Cosmochim Acta 41, 1375-1380.

22. Surour AA, El-Nisr SA, Bakhsh RA (2016) Origin of hydrous alkali feldspar-silica intergrowth in spherulites from intra-plate A2-type rhyolites at the Jabal shama, Saudi Arabia. J Afr Earth Sci 115, 92-107.

23. Zhao J, Li G, Evans NJ, Qin K, Li J, Zhang X (2016) Petrogenesis of Paleocene-Eocene porphyry depositrelated granitic rocks in the Aguila-Sharang ore district, central Lhasa terrane, Tibet. J Asian Earth Sci 129, 38-53.

24. Melluso L, Cucciniello C, Petrone CM, Lustrino M, Morra V, Tiepolo M, Vasconcelos L (2008) Petrology of Karoo volcanic rocks in the southern Lebombo Monocline, Mozambique. J Afr Earth Sci 52, 139-151.

25. Gałaś A (2014) Petrology and new data on the geochemistry of the Andahua volcanic group (central Andes, southern Peru). J South Am Earth Sci 56, 301-315.

26. Gioncada A, Orlandi P, Vezzoli L, Omarini RH, Mazzuoli R, Lopez-Azarevich V, Sureda R, Azarevich M, et al (2014) Topaz magmatic crystallization in rhyolites of the central Andes (Chivinar volcanic complex,
NW Argentina): constraints from texture, mineralogy and rock chemistry. Lithos 184-187, 62-73.

27. Mattioli M, Renzulli A, Menna M, Holm PM (2006) Rapid ascent and contamination of magmas through the thick crust of the CVS (Andes, ollagüe region): evidence from a nearly aphyric high-k andesite with skeletal olivines. $J$ Volcanol Geotherm Res 158, 87-105.

28. Singtuen M (2017) Geochemistry and tectonic setting of volcanic and associated rocks in Tak province. MS thesis, Chiang Mai Univ, Thailand.

29. Singharajwarapan S (1994) Deformation and metamorphism of the Sukhothai fold belt, northern Thailand. PhD thesis, Univ of Tasmania, Australia.

30. Srichan W, Crawford AJ, Berry RF (2009) Geochemistry and geochronology of late Triassic volcanic rocks in the Chiang Khong region, northern Thailand. Island Arc 18, 32-51.

31. Wipakul U (2012) Petrochemistry and age of volcanic rocks, Nan province, Thailand. MS thesis, Chiang Mai Univ, Thailand.

32. Barr SM, Macdonald AS, Dunning GR, Ounchanum P, Yaowanoiyothin W (2000) Petrochemistry, U-Pb (zircon) age, and palaeotectonic setting of the Lampang volcanic belt, northern Thailand. $J$ Geol Soc London 157, 553-563.

33. Barr SM, Macdonald AS, Ounchanum P, Hamilton MA (2006) Age, tectonic setting and regional implications of the Chiang Khong volcanic suite, northern Thailand. J Geol Soc London 163, 1037-1046.

34. Khositanont S, Ounchanum P, Panjasawatwong Y, Thanasuthipitak Th, Zaw K, Meffre S (2007) U$\mathrm{Pb}$ zircon ages and geochemical characteristics of Lampang-Phrae granites; implications for plate tectonic interpretation. In: Proceedings of the International Conference on Geology of Thailand Towards Sustainable Development and Sufficiency Economy, Bangkok, pp 367-372.

35. Srichan W (2008) Petrochemistry, Geochronology and tectonic implication of the Chiang KhongLumpang-Tak volcanic belt, northern, Thailand. $\mathrm{PhD}$ thesis, Univ of Tasmania, Australia.

36. Qian X, Wang Y, Feng Q, Zi JW, Zhang Y, Chonglakmani C (2016) Petrogenesis and tectonic implication of the late Triassic post-collisional volcanic rocks in Chiang Khong, NW Thailand. Lithos 248, 418-431.

37. Qian X, Feng Q, Chonglakmani C, Monjai D (2013) Geochemical and geochronological constrains on the Chiang Khong volcanic rocks (northwestern Thailand) and its tectonic implications. Front Earth Sci 7, 508-521.

38. Barber AJ, Crow MJ, Milson JS (2005) Sumatra: Geology, Resources and Tectonic Evolution, The Geological Society, London.

39. Hahn L (1984) The Indonesian orogeny in Thailand and adjacent areas: societe geologique de France. Memoire 147, 71-82. 


\section{Appendix A. Supplementary data}
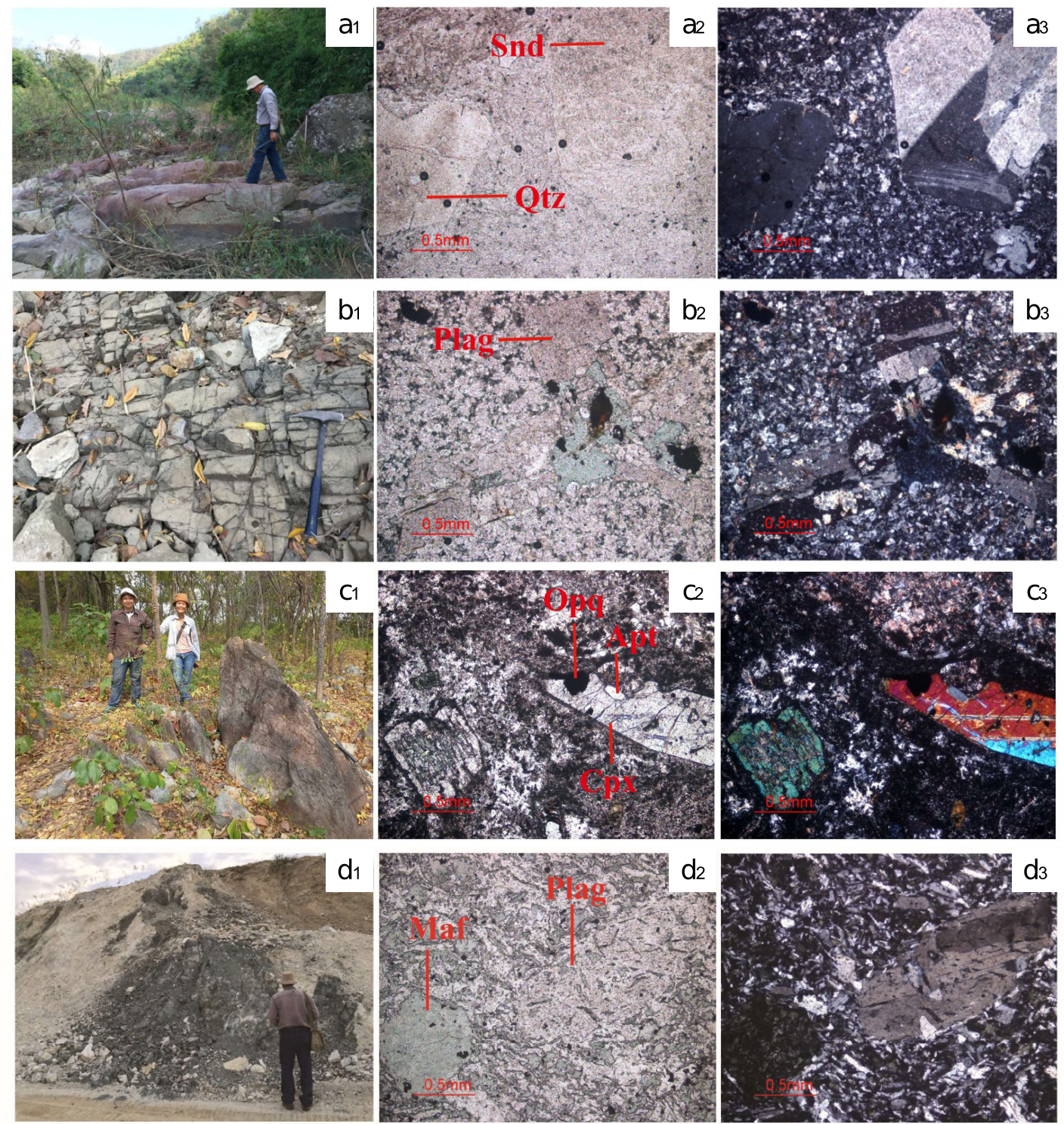

(1) outcrops (2) the photomicrographs with ordinary light (3) the photomicrographs with crossed polars

Fig. S1 (a) Rhyolite in the Mae Salaem area at grid reference 533774.0 E 1922471.7 N showing porphyritic texture with quartz (Qtz) and sanidine (Snd) phenocrysts; (b) rhyodacite in the Mae Phrik area at grid reference 516138.2 E 1912653.8 N illustrating plagioclase phenocrysts (Plag); (c) andesite porphyry in the Wang Prachop area at grid reference 534800.2 E $1873573.5 \mathrm{~N}$ showing inclusion of apatite (Apt) and opaque minerals (Opq) in clinopyroxene (Cpx); (d) basalt in the Mae Phrik area at grid reference 518 005.1 E $1914791.8 \mathrm{~N}$ showing unidentified mafic minerals phenocrysts (Maf) and plagioclase (Plag) in a very fine-grained groundmass. 
Table S1 Whole-rock analyses for geochemistry of the studied least-altered rocks; Mae Phrik (BTK) and Mae Salaem (MSL) areas.

\begin{tabular}{|c|c|c|c|c|c|c|}
\hline \multirow{2}{*}{ Sample } & \multicolumn{5}{|c|}{ BTK25 } & \multirow{2}{*}{$\frac{\text { MSL25 }}{1-1}$} \\
\hline & $1-1$ & $1-2^{*}$ & $7^{*}$ & $8-1$ & $8-3$ & \\
\hline \multicolumn{7}{|c|}{ Major oxides (wt\%) } \\
\hline $\mathrm{SiO}_{2}$ & 74.23 & 77.01 & 72.62 & 60.19 & 49.86 & 76.09 \\
\hline $\mathrm{TiO}_{2}^{2}$ & 0.23 & 0.23 & 0.37 & 0.92 & 1.82 & 0.07 \\
\hline $\mathrm{Al}_{2} \mathrm{O}_{3}$ & 12.47 & 12.73 & 12.61 & 17.13 & 18.89 & 12.26 \\
\hline $\mathrm{Fe}_{2} \mathrm{O}_{3}$ & 2.48 & 3.38 & 3.38 & 4.91 & 8.28 & 1.36 \\
\hline $\mathrm{MnO}$ & 0.03 & 0.02 & 0.08 & 0.09 & 0.13 & 0.06 \\
\hline $\mathrm{MgO}$ & 0.45 & 0.58 & 0.69 & 6.05 & 8.32 & 0.07 \\
\hline $\mathrm{CaO}$ & 1.73 & 0.08 & 2.11 & 0.62 & 1.06 & 0.35 \\
\hline $\mathrm{Na}_{2} \mathrm{O}$ & 1.79 & 0.54 & 4.22 & 6.42 & 6.43 & 3.05 \\
\hline $\mathrm{K}_{2} \mathrm{O}$ & 2.12 & 2.47 & 0.95 & 0.04 & 0.06 & 4.86 \\
\hline $\mathrm{P}_{2}^{2} \mathrm{O}_{5}$ & 0.04 & 0.04 & 0.07 & 0.33 & 0.77 & 0.01 \\
\hline LOI & 3.70 & 3.32 & 3.52 & 3.28 & 4.89 & 1.21 \\
\hline Sum & 99.28 & 100.41 & 100.62 & 99.97 & 100.50 & 99.38 \\
\hline \multicolumn{7}{|c|}{ Trace elements (ppm) } \\
\hline $\mathrm{Ni}$ & 3.23 & 6.37 & 5.88 & 109.54 & 165.16 & 3.21 \\
\hline V & 47.52 & 49.08 & 73.91 & 151.58 & 268.89 & 23.34 \\
\hline $\mathrm{Rb}$ & 91.94 & 114.26 & 35.22 & 5.68 & BD & 232.41 \\
\hline Y & 76.05 & 75.41 & 70.91 & $\mathrm{BD}$ & BD & 55.24 \\
\hline $\mathrm{Nb}$ & $\mathrm{BD}$ & $\mathrm{BD}$ & 0.39 & 23.02 & 39.73 & 12.23 \\
\hline Hf & & 4 & 4 & & 5 & 7 \\
\hline Th & 2.71 & 2.21 & 7.01 & 46.51 & 54.52 & 54.57 \\
\hline Ta & & 2 & 1.4 & & 1.1 & 2.4 \\
\hline $\mathrm{Cr}$ & 10.38 & 3.86 & 3.03 & 184.32 & 616.87 & 1.36 \\
\hline $\mathrm{Sr}$ & 63.08 & 61.61 & 92.06 & 171.82 & 75.42 & 107.24 \\
\hline $\mathrm{Ba}$ & 909.89 & 982.09 & 729.10 & 498.68 & 331.03 & 840.02 \\
\hline Sc & 6.53 & 0.42 & 9.76 & 1.44 & 3.50 & 2.79 \\
\hline $\mathrm{Zr}$ & 198.66 & 191.84 & 243.35 & 198.48 & 326.42 & 166.12 \\
\hline \multicolumn{7}{|c|}{ Rare Earth elements (ppm) } \\
\hline $\mathrm{La}$ & & 15.60 & 20.90 & & 295.00 & 40.50 \\
\hline $\mathrm{Ce}$ & & 32.70 & 39.30 & & 488.00 & 65.90 \\
\hline $\mathrm{Pr}$ & & 4.64 & 5.47 & & 50.18 & 7.01 \\
\hline $\mathrm{Nd}$ & & 21.10 & 23.50 & & 158.00 & 24.30 \\
\hline $\mathrm{Sm}$ & & 3.90 & 5.50 & & 18.60 & 4.00 \\
\hline $\mathrm{Eu}$ & & 1.17 & 1.40 & & 1.92 & 0.49 \\
\hline Gd & & 4.20 & 5.72 & & 16.70 & 3.73 \\
\hline $\mathrm{Tb}$ & & 0.77 & 1.12 & & 1.13 & 0.57 \\
\hline Dy & & 5.45 & 6.60 & & 3.92 & 3.11 \\
\hline Ho & & 1.32 & 1.51 & & 0.69 & 0.70 \\
\hline Er & & 3.81 & 4.16 & & 2.33 & 1.90 \\
\hline $\mathrm{Tm}$ & & 0.73 & 0.82 & & 0.35 & 0.39 \\
\hline $\mathrm{Yb}$ & & 4.10 & 4.70 & & 2.40 & 2.50 \\
\hline $\mathrm{Lu}$ & & 0.77 & 0.86 & & 0.53 & 0.42 \\
\hline \multicolumn{7}{|c|}{ Selected element ratios } \\
\hline $\mathrm{Ti} / \mathrm{Zr}$ & 7.07 & 7.23 & 9.20 & 27.79 & 33.48 & 2.47 \\
\hline $\mathrm{Zr} / \mathrm{Nb}$ & & & 623.97 & 8.62 & 8.22 & 13.58 \\
\hline $\mathrm{Zr} / \mathrm{Y}$ & 2.61 & 2.54 & 3.43 & & & 3.01 \\
\hline $\mathrm{Nb} / \mathrm{Y}$ & & & 0.01 & & & 0.22 \\
\hline $\mathrm{La} / \mathrm{Sm}^{\mathrm{cn}}$ & & 2.44 & 2.32 & & 9.67 & 6.17 \\
\hline $\mathrm{Sm} / \mathrm{Yb}^{\mathrm{cn}}$ & & 1.03 & 1.27 & & 8.40 & 1.73 \\
\hline
\end{tabular}

$\mathrm{BD}=$ below detection limit; $\mathrm{cn}=$ chondritenormalized values; ${ }^{*}$ Singtuen and Phajuy ${ }^{10}$.
Table S1: Continued

\begin{tabular}{|c|c|c|c|c|c|c|}
\hline \multirow{2}{*}{ Sample } & \multirow{2}{*}{$\frac{\text { PDNG30 }}{4}$} & \multicolumn{5}{|c|}{ WL29 } \\
\hline & & $1-1$ & $1-2$ & $1-3$ & $2-1$ & $2-2$ \\
\hline \multicolumn{7}{|c|}{ Major oxides (wt\%) } \\
\hline $\mathrm{SiO}_{2}$ & 49.95 & 48.43 & 47.28 & 46.15 & 48.19 & 51.85 \\
\hline $\mathrm{TiO}_{2}^{2}$ & 1.09 & 0.36 & 0.56 & 1.46 & 0.43 & 0.99 \\
\hline $\mathrm{Al}_{2} \mathrm{O}_{3}$ & 18.29 & 20.05 & 18.31 & 16.38 & 17.43 & 16.47 \\
\hline $\mathrm{Fe}_{2} \mathrm{O}_{3}^{3}$ & 9.89 & 7.76 & 10.07 & 12.43 & 7.48 & 8.78 \\
\hline $\mathrm{MnO}^{3}$ & 0.18 & 0.14 & 0.17 & 0.19 & 0.14 & 0.15 \\
\hline $\mathrm{MgO}$ & 4.00 & 5.96 & 7.79 & 6.54 & 7.77 & 7.09 \\
\hline $\mathrm{CaO}$ & 6.46 & 11.64 & 10.31 & 12.81 & 15.01 & 7.62 \\
\hline $\mathrm{Na}_{2} \mathrm{O}$ & 4.74 & 1.86 & 1.15 & 0.99 & 1.42 & 2.71 \\
\hline $\mathrm{K}_{2} \mathrm{O}$ & 0.12 & 0.20 & 0.29 & 0.08 & 0.11 & 0.09 \\
\hline $\mathrm{P}_{2}^{2} \mathrm{O}_{5}$ & 0.22 & 0.07 & 0.07 & 0.02 & 0.01 & 0.27 \\
\hline $\mathrm{LOI}^{5}$ & 5.67 & 3.59 & 3.72 & 2.89 & 2.61 & 3.57 \\
\hline Sum & 100.60 & 100.04 & 99.73 & 99.95 & 100.60 & 99.58 \\
\hline \multicolumn{7}{|c|}{ Trace elements (ppm) } \\
\hline $\mathrm{Ni}$ & 17.10 & 15.76 & 17.85 & 9.25 & 9.48 & 99.74 \\
\hline $\mathrm{V}$ & 165.80 & 63.18 & 83.70 & 227.44 & 72.68 & 139.82 \\
\hline $\mathrm{Rb}$ & 10.05 & 10.75 & 12.64 & 8.45 & 8.53 & 8.49 \\
\hline $\mathrm{Y}$ & 29.46 & 7.84 & 5.52 & 6.11 & 6.02 & 19.34 \\
\hline $\mathrm{Nb}$ & 2.85 & 0.73 & 2.06 & 1.49 & 0.99 & 7.07 \\
\hline $\mathrm{Hf}$ & 5 & 2 & & & & 5 \\
\hline Th & 5.45 & 0.10 & 1.32 & 2.12 & 0.40 & 6.02 \\
\hline Тa & 1 & 0.4 & & & & 1.8 \\
\hline $\mathrm{Cr}$ & 24.59 & 127.50 & 184.02 & 271.72 & 64.36 & 349.21 \\
\hline $\mathrm{Sr}$ & 668.91 & 366.54 & 297.43 & 336.65 & 318.26 & 387.41 \\
\hline $\mathrm{Ba}$ & 550.87 & 658.91 & 630.38 & 433.80 & 636.67 & 538.44 \\
\hline $\mathrm{Sc}$ & 18.55 & 31.75 & 30.44 & 35.58 & 41.16 & 23.53 \\
\hline $\mathrm{Zr}$ & 152.18 & 48.45 & 42.85 & 48.80 & 45.27 & 136.29 \\
\hline \multicolumn{7}{|c|}{ Rare Earth elements (ppm) } \\
\hline $\mathrm{La}$ & 17.20 & 3.10 & & & & 20.50 \\
\hline $\mathrm{Ce}$ & 32.10 & 5.20 & & & & 39.90 \\
\hline $\mathrm{Pr}$ & 4.39 & 0.74 & & & & 5.28 \\
\hline $\mathrm{Nd}$ & 18.70 & 3.20 & & & & 21.70 \\
\hline $\mathrm{Sm}$ & 4.50 & 0.90 & & & & 4.10 \\
\hline Eu & 1.36 & 1.10 & & & & 1.25 \\
\hline Gd & 4.33 & 0.66 & & & & 3.87 \\
\hline $\mathrm{Tb}$ & 0.72 & 0.10 & & & & 0.65 \\
\hline Dy & 4.24 & 0.78 & & & & 3.35 \\
\hline Ho & 0.95 & 0.18 & & & & 0.71 \\
\hline Er & 2.57 & 0.49 & & & & 1.78 \\
\hline $\mathrm{Tm}$ & 0.46 & 0.10 & & & & 0.33 \\
\hline $\mathrm{Yb}$ & 2.60 & 0.60 & & & & 1.80 \\
\hline $\mathrm{Lu}$ & 0.44 & 0.09 & & & & 0.29 \\
\hline \multicolumn{7}{|c|}{ Selected element ratios } \\
\hline $\mathrm{Ti} / \mathrm{Zr}$ & 42.79 & 44.46 & 77.83 & 179.36 & 56.85 & 43.69 \\
\hline $\mathrm{Zr} / \mathrm{Nb}$ & 53.40 & 66.37 & 20.80 & 32.75 & 45.73 & 19.28 \\
\hline $\mathrm{Zr} / \mathrm{Y}$ & 5.17 & 6.18 & 7.76 & 7.99 & 7.52 & 7.05 \\
\hline $\mathrm{Nb} / \mathrm{Y}$ & 0.10 & 0.09 & 0.37 & 0.24 & 0.16 & 0.37 \\
\hline $\mathrm{La} / \mathrm{Sm}^{\mathrm{cn}}$ & 2.33 & 2.10 & & & & 3.05 \\
\hline $\mathrm{Sm} / \mathrm{Yb}^{\mathrm{cn}}$ & 1.88 & 1.63 & & & & 2.47 \\
\hline
\end{tabular}


Table S1: Continued

\begin{tabular}{|c|c|c|c|c|c|c|}
\hline \multirow{2}{*}{ Sample } & \multirow{2}{*}{$\frac{\text { WL29 }}{3}$} & \multicolumn{5}{|c|}{ WPC26 } \\
\hline & & $3-1^{*}$ & 4 & $7^{* * *}$ & $10^{* * *}$ & $11^{* *}$ \\
\hline \multicolumn{7}{|c|}{ Major oxides (wt\%) } \\
\hline $\mathrm{SiO}_{2}$ & 47.97 & 80.11 & 57.69 & 60.30 & 57.28 & 57.47 \\
\hline $\mathrm{TiO}_{2}^{2}$ & 1.24 & 0.05 & 0.87 & 0.69 & 0.85 & 0.86 \\
\hline $\mathrm{Al}_{2} \mathrm{O}_{3}$ & 16.94 & 12.40 & 17.51 & 16.16 & 16.24 & 16.43 \\
\hline $\mathrm{Fe}_{2}^{2} \mathrm{O}_{3}^{3}$ & 10.44 & 0.83 & 6.90 & 6.27 & 7.04 & 7.21 \\
\hline $\mathrm{MnO}^{3}$ & 0.16 & 0.01 & 0.16 & 0.11 & 0.12 & 0.13 \\
\hline $\mathrm{MgO}$ & 7.83 & 0.10 & 2.24 & 3.06 & 3.94 & 3.97 \\
\hline $\mathrm{CaO}$ & 6.24 & 0.07 & 3.27 & 5.99 & 5.95 & 5.44 \\
\hline $\mathrm{Na}_{2} \mathrm{O}$ & 2.42 & 2.24 & 3.45 & 2.36 & 2.22 & 2.69 \\
\hline $\mathrm{K}_{2} \mathrm{O}$ & 2.46 & 2.69 & 4.67 & 2.26 & 2.67 & 2.21 \\
\hline $\mathrm{P}_{2}^{2} \mathrm{O} 5$ & 0.23 & 0.01 & 0.32 & 0.14 & 0.20 & 0.20 \\
\hline LOI & 4.31 & 1.57 & 2.08 & 2.19 & 3.50 & 3.26 \\
\hline Sum & 100.23 & 100.09 & 99.15 & 99.53 & 100.03 & 99.86 \\
\hline \multicolumn{7}{|c|}{ Trace elements (ppm) } \\
\hline $\mathrm{Ni}$ & 60.85 & 8.09 & 5.53 & 18.53 & 40.15 & 39.42 \\
\hline V & 189.04 & 31.48 & 134.73 & 101.06 & 126.38 & 126.37 \\
\hline $\mathrm{Rb}$ & 75.95 & 173.23 & 145.52 & 76.62 & 100.94 & 87.41 \\
\hline Y & 38.77 & 75.90 & 74.48 & 48.00 & 46.38 & 44.57 \\
\hline $\mathrm{Nb}$ & 3.01 & 6.02 & 6.57 & 5.91 & 6.76 & 5.73 \\
\hline $\mathrm{Hf}$ & 3 & 3 & 4 & & & \\
\hline Th & 1.47 & 25.58 & 6.58 & 8.25 & 7.33 & 6.75 \\
\hline Тa & 1.4 & 1.5 & 1.6 & & & \\
\hline $\mathrm{Cr}$ & 225.07 & 15.66 & 9.27 & 80.78 & 121.31 & 118.88 \\
\hline $\mathrm{Sr}$ & 257.13 & 114.35 & 357.31 & 337.70 & 395.40 & 356.38 \\
\hline $\mathrm{Ba}$ & 748.39 & 1533.07 & 1071.15 & 782.09 & 834.70 & 789.58 \\
\hline $\mathrm{Sc}$ & 21.99 & 3.94 & 11.42 & 18.28 & 20.16 & 15.28 \\
\hline $\mathrm{Zr}$ & 102.93 & 128.09 & 247.45 & 172.92 & 169.32 & 170.36 \\
\hline \multicolumn{7}{|c|}{ Rare Earth elements (ppm) } \\
\hline $\mathrm{La}$ & 7.50 & 14.70 & 26.30 & & & \\
\hline $\mathrm{Ce}$ & 19.10 & 25.80 & 54.20 & & & \\
\hline $\mathrm{Pr}$ & 3.08 & 3.96 & 7.33 & & & \\
\hline $\mathrm{Nd}$ & 14.40 & 14.70 & 30.40 & & & \\
\hline $\mathrm{Sm}$ & 3.30 & 2.80 & 5.50 & & & \\
\hline $\mathrm{Eu}$ & 1.21 & 0.86 & 2.06 & & & \\
\hline $\mathrm{Gd}$ & 3.31 & 3.01 & 6.09 & & & \\
\hline $\mathrm{Tb}$ & 0.67 & 0.58 & 1.02 & & & \\
\hline Dy & 3.68 & 3.78 & 6.00 & & & \\
\hline Ho & 0.80 & 0.96 & 1.31 & & & \\
\hline Er & 2.16 & 2.80 & 3.36 & & & \\
\hline $\mathrm{Tm}$ & 0.39 & 0.50 & 0.63 & & & \\
\hline $\mathrm{Yb}$ & 2.20 & 3.20 & 3.60 & & & \\
\hline $\mathrm{Lu}$ & 0.36 & 0.53 & 0.64 & & & \\
\hline \multicolumn{7}{|c|}{ Selected element ratios } \\
\hline $\mathrm{Ti} / \mathrm{Zr}$ & 71.99 & 2.55 & 20.99 & 23.86 & 30.21 & 30.41 \\
\hline $\mathrm{Zr} / \mathrm{Nb}$ & 34.20 & 21.28 & 37.66 & 29.26 & 25.05 & 29.73 \\
\hline $\mathrm{Zr} / \mathrm{Y}$ & 2.65 & 1.69 & 3.32 & 3.60 & 3.65 & 3.82 \\
\hline $\mathrm{Nb} / \mathrm{Y}$ & 0.08 & 0.08 & 0.09 & 0.12 & 0.15 & 0.13 \\
\hline $\mathrm{La} / \mathrm{Sm}^{\mathrm{cn}}$ & 1.39 & 3.20 & 2.91 & & & \\
\hline $\mathrm{Sm} / \mathrm{Yb}^{\mathrm{cn}}$ & 1.63 & 0.95 & 1.66 & & & \\
\hline
\end{tabular}

"Singtuen and Phajuy ${ }^{10} ;{ }^{* *}$ Singtuen and Phajuy ${ }^{11}$.
Table S1: Continued

\begin{tabular}{|c|c|c|c|c|c|c|}
\hline \multirow{2}{*}{ Sample } & \multirow{2}{*}{$\frac{\text { WPC26 }}{12^{* * *}}$} & \multicolumn{2}{|c|}{ WPC27 } & \multicolumn{3}{|c|}{ WCH26 } \\
\hline & & $2^{* *}$ & $3^{* * *}$ & $2-1 *$ & $2-2^{*}$ & $3-1$ \\
\hline \multicolumn{7}{|c|}{ Major oxides (wt\%) } \\
\hline $\mathrm{SiO}_{2}$ & 60.17 & 60.40 & 61.39 & 78.22 & 77.78 & 77.14 \\
\hline $\mathrm{TiO}_{2}^{2}$ & 0.75 & 0.73 & 0.76 & 0.05 & 0.06 & 0.05 \\
\hline $\mathrm{Al}_{2} \mathrm{O}_{3}$ & 16.29 & 16.29 & 16.37 & 12.36 & 12.03 & 12.07 \\
\hline $\mathrm{Fe}_{2} \mathrm{O}_{3}$ & 6.52 & 6.34 & 5.98 & 0.32 & 0.53 & 0.85 \\
\hline $\mathrm{MnO}^{2}$ & 0.11 & 0.12 & 0.14 & 0.01 & 0.01 & 0.02 \\
\hline $\mathrm{MgO}$ & 2.74 & 3.01 & 2.91 & 0.02 & 0.02 & 0.12 \\
\hline $\mathrm{CaO}$ & 5.37 & 3.73 & 2.84 & 0.06 & 0.06 & 0.32 \\
\hline $\mathrm{Na}_{2} \mathrm{O}$ & 2.57 & 2.58 & 5.50 & 2.59 & 1.88 & 3.26 \\
\hline $\mathrm{K}_{2} \mathrm{O}$ & 2.36 & 3.82 & 0.64 & 5.66 & 6.80 & 4.37 \\
\hline $\mathrm{P}_{2}^{2} \mathrm{O}_{5}$ & 0.17 & 0.16 & 0.17 & 0.01 & 0.00 & 0.00 \\
\hline LOI $^{5}$ & 2.56 & 2.74 & 3.40 & 1.05 & 1.08 & 1.22 \\
\hline Sum & 99.60 & 99.92 & 100.09 & 100.34 & 100.26 & 99.42 \\
\hline \multicolumn{7}{|c|}{ Trace elements (ppm) } \\
\hline $\mathrm{Ni}$ & 17.93 & 11.47 & 7.14 & 8.55 & 2.60 & 8.28 \\
\hline $\mathrm{V}$ & 112.90 & 108.44 & 116.84 & 20.72 & 21.46 & 20.64 \\
\hline $\mathrm{Rb}$ & 87.43 & 133.79 & 32.93 & 386.84 & 466.07 & 427.34 \\
\hline $\mathrm{Y}$ & 46.25 & 59.73 & 43.91 & 89.10 & 109.72 & 130.44 \\
\hline $\mathrm{Nb}$ & 5.73 & 4.87 & 4.54 & 31.64 & 33.47 & 45.84 \\
\hline $\mathrm{Hf}$ & 4 & & 8 & & & \\
\hline Th & 8.04 & 7.56 & 9.38 & 78.25 & 75.81 & 65.75 \\
\hline $\mathrm{Ta}$ & 1.4 & & 1.5 & & & \\
\hline $\mathrm{Cr}$ & 54.77 & 59.91 & 48.63 & 2.52 & 2.69 & 23.27 \\
\hline $\mathrm{Sr}$ & 318.69 & 331.52 & 335.50 & 104.70 & 105.95 & 94.75 \\
\hline $\mathrm{Ba}$ & 781.50 & 1112.28 & 694.35 & 820.86 & 877.15 & 858.51 \\
\hline Sc & 17.74 & 14.31 & 10.30 & 1.25 & 3.54 & 0.79 \\
\hline $\mathrm{Zr}$ & 172.34 & 189.07 & 210.26 & 179.43 & 182.05 & 157.06 \\
\hline \multicolumn{7}{|c|}{ Rare Earth elements (ppm) } \\
\hline $\mathrm{La}$ & 24.70 & & 28.70 & & & \\
\hline $\mathrm{Ce}$ & 46.60 & & 50.20 & & & \\
\hline $\operatorname{Pr}$ & 6.08 & & 6.92 & & & \\
\hline $\mathrm{Nd}$ & 23.90 & & 28.30 & & & \\
\hline $\mathrm{Sm}$ & 4.20 & & 4.90 & & & \\
\hline Eu & 1.31 & & 1.29 & & & \\
\hline Gd & 4.60 & & 5.34 & & & \\
\hline $\mathrm{Tb}$ & 0.80 & & 0.91 & & & \\
\hline Dy & 4.36 & & 4.97 & & & \\
\hline Ho & 0.99 & & 1.09 & & & \\
\hline Er & 2.27 & & 2.75 & & & \\
\hline $\mathrm{Tm}$ & 0.40 & & 0.50 & & & \\
\hline $\mathrm{Yb}$ & 2.40 & & 2.70 & & & \\
\hline $\mathrm{Lu}$ & 0.44 & & 0.51 & & & \\
\hline \multicolumn{7}{|c|}{ Selected element ratios } \\
\hline $\mathrm{Ti} / \mathrm{Zr}$ & 26.03 & 23.06 & 21.59 & 1.65 & 1.92 & 2.00 \\
\hline $\mathrm{Zr} / \mathrm{Nb}$ & 30.08 & 38.82 & 46.31 & 5.67 & 5.44 & 3.43 \\
\hline $\mathrm{Zr} / \mathrm{Y}$ & 3.73 & 3.17 & 4.79 & 2.01 & 1.66 & 1.20 \\
\hline $\mathrm{Nb} / \mathrm{Y}$ & 0.12 & 0.08 & 0.10 & 0.36 & 0.31 & 0.35 \\
\hline $\mathrm{La} / \mathrm{Sm}^{\mathrm{cn}}$ & 3.58 & & 3.57 & & & \\
\hline $\mathrm{Sm} / \mathrm{Yb}^{\mathrm{cn}}$ & 1.90 & & 1.97 & & & \\
\hline
\end{tabular}

"Singtuen and Phajuy ${ }^{10 ;}$; Singtuen and Phajuy ${ }^{11}$. 
Table S1: Continued

\begin{tabular}{|c|c|c|c|c|c|c|}
\hline \multirow{2}{*}{ Sample } & \multicolumn{3}{|c|}{ WCH26 } & \multirow{2}{*}{$\frac{\mathrm{WCH} 27}{5-2^{*}}$} & \multicolumn{2}{|c|}{ WCH28 } \\
\hline & $3-2^{*}$ & $4^{*}$ & $5^{*}$ & & 4 & $8-1$ \\
\hline \multicolumn{7}{|c|}{ Major oxides (wt\%) } \\
\hline $\mathrm{SiO}_{2}$ & 76.94 & 78.07 & 78.33 & 72.79 & 62.52 & 53.47 \\
\hline $\mathrm{TiO}_{2}$ & 0.05 & 0.05 & 0.13 & 0.31 & 0.78 & 1.56 \\
\hline $\mathrm{Al}_{2} \mathrm{O}_{3}$ & 13.09 & 11.98 & 12.47 & 13.66 & 16.53 & 17.93 \\
\hline $\mathrm{Fe}_{2} \mathrm{O}_{3}$ & 0.72 & 0.72 & 1.03 & 2.06 & 5.35 & 8.67 \\
\hline $\mathrm{MnO}$ & 0.02 & 0.01 & 0.01 & 0.03 & 0.12 & 0.17 \\
\hline $\mathrm{MgO}$ & 0.08 & 0.10 & 0.20 & 0.35 & 1.83 & 4.12 \\
\hline $\mathrm{CaO}$ & 0.12 & 0.26 & 0.04 & 0.16 & 4.35 & 2.33 \\
\hline $\mathrm{Na}_{2} \mathrm{O}$ & 3.15 & 3.52 & 0.11 & 3.77 & 3.72 & 4.41 \\
\hline $\mathrm{K}_{2} \mathrm{O}$ & 4.68 & 4.01 & 6.09 & 4.84 & 1.92 & 1.46 \\
\hline $\mathrm{P}_{2} \mathrm{O}_{5}$ & 0.00 & 0.01 & 0.01 & 0.05 & 0.23 & 0.57 \\
\hline LOI & 1.08 & 1.07 & 2.09 & 1.46 & 1.92 & 4.78 \\
\hline Sum & 99.94 & 99.78 & 100.54 & 99.49 & 99.26 & 99.46 \\
\hline \multicolumn{7}{|c|}{ Trace elements (ppm) } \\
\hline $\mathrm{Ni}$ & 0.85 & 12.93 & 6.61 & 6.08 & 2.81 & 85.39 \\
\hline $\mathrm{V}$ & 19.54 & 19.98 & 31.08 & 63.56 & 130.25 & 268.35 \\
\hline $\mathrm{Rb}$ & 341.08 & 273.65 & 405.14 & 183.24 & 80.67 & 77.89 \\
\hline $\mathrm{Y}$ & 110.87 & 95.04 & 106.75 & 83.16 & 44.95 & 42.96 \\
\hline $\mathrm{Nb}$ & 30.94 & 27.45 & 20.52 & 17.46 & 6.73 & 14.00 \\
\hline Hf & & 5 & & 5 & 4 & 2 \\
\hline Th & 77.76 & 79.27 & 72.93 & 30.10 & 12.00 & 17.50 \\
\hline Ta & & 1.4 & & 2.8 & 1.3 & 0.6 \\
\hline $\mathrm{Cr}$ & 0.41 & 4.06 & 5.88 & 1.33 & 13.00 & 194.16 \\
\hline $\mathrm{Sr}$ & 78.56 & 91.12 & 91.47 & 116.31 & 396.66 & 178.88 \\
\hline $\mathrm{Ba}$ & 761.54 & 766.07 & 959.61 & 929.93 & 850.67 & 576.52 \\
\hline $\mathrm{Sc}$ & 2.50 & 0.66 & 2.41 & 2.27 & 14.87 & 6.45 \\
\hline $\mathrm{Zr}$ & 174.24 & 188.89 & 385.39 & 371.44 & 211.32 & 228.59 \\
\hline \multicolumn{7}{|c|}{ Rare Earth elements (ppm) } \\
\hline $\mathrm{La}$ & & 17.20 & & 38.50 & 29.80 & 40.80 \\
\hline $\mathrm{Ce}$ & & 27.50 & & 71.30 & 55.90 & 69.90 \\
\hline $\operatorname{Pr}$ & & 5.69 & & 9.05 & 6.86 & 10.78 \\
\hline $\mathrm{Nd}$ & & 24.60 & & 33.80 & 27.00 & 43.90 \\
\hline $\mathrm{Sm}$ & & 6.50 & & 5.00 & 5.60 & 6.90 \\
\hline $\mathrm{Eu}$ & & 0.27 & & 1.22 & 1.62 & 2.33 \\
\hline Gd & & 6.24 & & 5.32 & 4.60 & 6.91 \\
\hline $\mathrm{Tb}$ & & 1.22 & & 0.98 & 0.83 & 0.94 \\
\hline Dy & & 6.77 & & 5.54 & 4.21 & 5.35 \\
\hline Ho & & 1.40 & & 1.21 & 0.89 & 1.06 \\
\hline Er & & 3.49 & & 3.37 & 2.35 & 2.77 \\
\hline $\mathrm{Tm}$ & & 0.69 & & 0.62 & 0.44 & 0.47 \\
\hline $\mathrm{Yb}$ & & 4.00 & & 3.60 & 2.60 & 2.50 \\
\hline $\mathrm{Lu}$ & & 0.62 & & 0.63 & 0.42 & 0.42 \\
\hline \multicolumn{7}{|c|}{ Selected element ratios } \\
\hline $\mathrm{Ti} / \mathrm{Zr}$ & 1.77 & 1.57 & 1.97 & 5.02 & 21.99 & 40.81 \\
\hline $\mathrm{Zr} / \mathrm{Nb}$ & 5.63 & 6.88 & 18.78 & 21.27 & 31.40 & 16.33 \\
\hline $\mathrm{Zr} / \mathrm{Y}$ & 1.57 & 1.99 & 3.61 & 4.47 & 4.70 & 5.32 \\
\hline $\mathrm{Nb} / \mathrm{Y}$ & 0.28 & 0.29 & 0.19 & 0.21 & 0.15 & 0.33 \\
\hline $\mathrm{La} / \mathrm{Sm}^{\mathrm{cn}}$ & & 1.61 & & 4.69 & 3.24 & 3.60 \\
\hline $\mathrm{Sm} / \mathrm{Yb}^{\mathrm{cn}}$ & & 1.76 & & 1.50 & 2.33 & 2.99 \\
\hline
\end{tabular}

* Singtuen and Phajuy ${ }^{10}$. 